\title{
Colin Barr, Ireland's Empire. The Roman Catholic Church in the English-Speaking World, 1829-1914
}

\section{Alexandra Slaby}

\section{OpenEdition}

1 Journals

\section{Édition électronique}

URL : https://journals.openedition.org/etudesirlandaises/10432

DOI : 10.4000/etudesirlandaises. 10432

ISSN : 2259-8863

\section{Éditeur}

Presses universitaires de Caen

\section{Édition imprimée}

Date de publication : 31 décembre 2020

Pagination : 213-215

ISBN : 978-2-84133-996-9

ISSN : 0183-973X

\section{Référence électronique}

Alexandra Slaby, "Colin Barr, Ireland's Empire. The Roman Catholic Church in the English-Speaking World, 1829-1914 », Études irlandaises [En ligne], 45-2 | 2020, mis en ligne le 31 décembre 2020, consulté le 17 novembre 2022. URL : http://journals.openedition.org/etudesirlandaises/10432 ; DOI : https://doi.org/ 10.4000/etudesirlandaises. 10432

\section{(c) (i) (2) (2)}

Creative Commons - Attribution - Pas d'Utilisation Commerciale - Partage dans les Mêmes Conditions 4.0 International - CC BY-NC-SA 4.0

https://creativecommons.org/licenses/by-nc-sa/4.0/ 
countries she visited. The last chapter is devoted to her final book, Autobiography of a Child (1899). It is one of her most well-known pieces, a narrative that challenges the novel genre, and that is full of intertextual references. The study describes this work as one that gathers all the crucial questions of the Lynch oeuvre: the role of women in society, the impacts of gender on identity formation, and the quest of women towards independence and self-expression.

It can be stated that this study is not only an engaging and interesting collection but also an important and missing element from the puzzle that is the tradition of Irish women's writing. The cross-references within the chapters provide an almost pedagogical guidance into the life of Hannah Lynch as well as into the respective historical period. The anecdotes, authentic passages, reviews, and correspondences are harmoniously aligned with the professional critical analysis of the works. Although Lynch died at a very young age, her legacy is now revived in this thoroughly engaging book to prove that she was way more than a "bibliographical curiosity from the sharp end of the $19^{\text {th }}$ century" (p. 5).

Orsolya Szücs

\section{Colin Barr, Ireland's Empire. The Roman Catholic Church in the English- Speaking World, 1829-1914, Cambridge, Cambridge University Press, $2020, \mathrm{xvi}+566 \mathrm{p}$.}

Canadian-born Colin Barr received his $\mathrm{PhD}$ from Cambridge and held academic positions in Ireland and the United States prior to his current post as senior lecturer at the school of divinity, history and philosophy at the University of Aberdeen. His work on Paul Cullen, Archbishop of Dublin (1852-1878) and Ireland's first cardinal (1866), is well known to Irish Studies scholars (Paul Cullen, John Henry Newman, and the Catholic University of Ireland, 1845-1865, Notre Dame, University of Notre Dame Press, 2003). He now offers us a magisterial volume which is poised to become the authoritative study of "Greater Ireland".

Building on his earlier research, Barr presents the rich harvest of his work on new Cullen-related material discovered in Australia in 2004 and on 104 archives scattered across twelve countries on five continents. The organic metaphor applies here: the growth of such a substantial, solid, comprehensive body of work requires an abundance of time - in this case sixteen years. The fruit appears as soon as you delve into the book: the map of Greater Ireland, an ecclesiastical, cultural and political universe structured by the "global Cullenite network" (p. 283), and one that is charted here with a scholarly rigour perfectly balanced with an engaging style laced with dry humour.

The book is divided into seven chapters, each of which is a world in itself with its own dynamics and personalities: the United States, Newfoundland, India, South 
Africa, Canada, Australia, New Zealand. Australia enjoys a strong focus, which Barr readily admits, for obvious reasons pertaining to his previous research. The author also acknowledges having left out entire regions, such as South America. Such a choice is understandable, given that the area is already extensively researched from that perspective by Dermot Keogh (Church and Politics in Latin America, London, Palgrave Macmillan, 1990; and another title forthcoming). In the regions Barr has studied, he notes a relative paucity of research by academic historians. Indeed, the secondary sources - based on papers in diocesan and congregational archives - that have been produced so far have amounted to a few confessional publications on the Irish missionary movement (Edmund M. Hogan, The Irish Missionary Movement [1990], $2^{\text {nd }}$ ed., Dublin, Gill and Macmillan, 1992), on the missionary endeavours of particular orders, and a handful of biographies of prominent bishops. However, such publications are most often confessional, hagiographic and pious. Valuable in themselves, they should perhaps be treated as primary sources. Other studies have been published, but their scope was limited in various ways and they are now dated ${ }^{1}$. The time had come for a substantive post-pious study, and Barr has delivered it.

Such a project could easily have read as a long genealogy of "Hiberno-Roman" episcopal appointments, or an arid chronology of the battles between the Irish, Scottish, English, French, Italian secular and regular clergy as they competed to save souls for God - and for Ireland. Instead, this book reads as a novel which is at times hard to put down, so absorbing and entertaining are the stories, intrigues and characterisations of clerics all the way up from the vagabondi priests thrown out of all places for their unedifying behaviour to the Propaganda in the "vestibule of Paradise". All those endeavours were bound by an intricate web of communication spun from Dublin by Cullen on the strength of his closeness to Rome and of his global network of clerical cousins.

Finally, Barr places the results of his study in a broader cultural framework of identity formation and retention in the Irish diasporic world. He reveals the mechanisms whereby loyalties that could be seen as conflicting at home (Irish and imperial for example) could live together in the hearts and minds of the diasporic Irish. And on the strength of this body of research, he analyses the role that the Irish Catholic Church has had in perpetuating an exceptionally strong and enduring loyalty across Greater Ireland to Hiberno-Roman Catholicism and Irish political aspirations, and in colouring ("greening") Catholicism in the English-speaking world.

From the perspective of my own current research into Irish-South African Catholicism, I wholeheartedly welcome this publication and am grateful for Barr's work, as it not only fills lacunae, but also justifies the enduring importance of

1. A History of Irish Catholicism, Patrick J. Corish (ed.), Dublin, Gill and Macmillan, 1971, vol. VI.3: Canada, 4: South Africa, 5: South America. Contributions by journalists and amateur historians: Joe Humphreys, God's Entrepreneurs. How Irish Missionaries Tried to Save the World, Dublin, New Island, 2010; Marian Keaney, They Brought the Good News: Modern Irish Missionaries, Dublin, Veritas, 1981; and Irish Missionaries from the Golden Age to the $20^{\text {th }}$ century, Dublin, Veritas, 1984. 
academic religious studies and shows the way in tone and approach for future research into what Barr has convincingly described as the first and "only truly global institution the world has ever known" (p. 1).

Alexandra SLABY

\section{How Popular Culture Travels, Sylvie Mikowski, Yann Philippe (eds.), Reims, ÉPURE, 2019, 237 p.}

In the Introduction to their thought-provoking and thoroughly enjoyable volume How Popular Culture Travels, Mikowski and Philippe invite us on an archaeological dig through the multiple strata of complex cultural exchanges to uncover the bedrock of connections that form the essence of intercultural transfer - and, dare I say it, they have unearthed some gems... The starting point for the dig clearly illustrates the difficulty and the importance of reaching this bedrock: the origin of the song Drill Ye Tarriers, Drill is unclear, but given the highly pejorative connotation of the word tarrier to designate Irish and Scots Roman Catholics, it is difficult to imagine it being popular among Irish Americans before the New York Irish comic singer Thomas Casey published and popularised it in the 1880s as Drill Ye Terriers, Drill. Through John Ford's 1924 film The Iron Horse it then came to symbolically underline "the singular contribution [of Irish-Americans] [...] to the crucible of American culture" (p. 10), but the tangled roots of the song demonstrate the potential pitfalls in the study of how popular culture travels.

The book explores intercultural transfers between Ireland and the United States through wide-ranging contributions dealing with $19^{\text {th }}$ century music and art, to punk music and Internet memes. Each chapter examines how the "basic units of cultural transmission" travel between and within cultures. The "viral" nature of the dissemination of these basic units, or memes, a term first coined by the evolutionary biologist Richard Dawkins in the 1970s, corroborates the theory on the cultural transmission of art developed by Leo Tolstoy, and which is based on the "infectiousness" of cultural elements that pass from one individual to another (Leo Tolstoy, What is Art?, Indianapolis, Hackett Publishing Company, 1960).

To continue the viral metaphor, as the memes are disseminated they seem to depend, at least partly, on "super-spreaders", or what, in more cultural terms, would be known as an opinion-maker or a social media influencer if we're dealing with the Web. In Adèle Commins' chapter on the reception of Charles Villiers Stanford's music in $19^{\text {th }}$ century USA, music critics, including Richard Aldrich and Henry Krehbiel, promoted Stanford's music through their writings in newspapers such as The New York Times and The New York Tribune. Similarly, Amélie Dochy's chapter on the $19^{\text {th }}$ century Scottish painter Erskine Nicol demonstrates the importance of an international network of some British art dealers, in particular Arthur Tooth 